\title{
Ectopic Parathyroid Adenoma: A Rare Mediastinal Tumor
}

\author{
Ektopik Paratiroid Adenomu: Nadir Bir Mediastinal Tümör
}

Orkide Kutlu', Mustafa Çalık², Cevdet Duran ${ }^{3}$, Hıdır Esme ${ }^{2}$, Omer Karahan $^{4}$

\begin{abstract}
Primary hyperparathyroidism is generally due to a solitary parathyroid adenoma and among those adenomas, $1 \%$ have been reported to have an ectopic mediastinal location. In the diagnosis of ectopic parathyroid adenoma, technetium-99m methoxyisobutylisonitrile scintigraphy is an imaging method with a sensitivity of approximately 100\%; however, in preoperative localization of the tumor, it should be evaluated together with magnetic resonance imaging and/or computed tomography images. In general, the treatment necessitates a cervical approach that may require a sternotomy, though rarely, an anterolateral thoracotomy is warranted. Recently, especially in visceral tumors, an effective and comfortable treatment option has been defined with video assisted thoracoscopic surgery. The aim of this article was to report the successful excision of a mediastinal parathyroid adenoma with a lateral thoracotomic approach that was localized with Tc- $99 \mathrm{~m}$ MIBI scintigraphy and single-photon emission computed tomography imaging in a patient with ongoing clinical and laboratory findings of HPT after the first operation, in which a general surgical team performed a total thyroidectomy and parathyroidectomy. The patient is still in follow-up with L-thyroxine, calcium, and vitamin $D$ replacement treatment.
\end{abstract}

Key words: Hyperparathyroidism, adenoma, mediastinal, thoracotomy.

\section{Özet}

Primer hiperparatiroidizm (PHPT) genellikle soliter paratiroid adenomuna bağlıdır ve bu adenomların $\% 1$ 'inde ektopik mediastinal yerleşim olduğu bildirilmiştir. Ektopik paratiroid adenomu tanısında Tc99mMIBI sintigrafisi, yaklaşık \%100 duyarlılı̆ı vardır; ancak tümörün preoperatif lokalizasyonu belirlenmesi için MR ve / veya BT görüntüleri ile birlikte değerlendirilmelidir. Genelde tedavisi sternotomi gerektirebilen servikal yaklaşım, nadiren de antero-lateral torakotomidir. Son zamanlarda özellikle viseral tümörlerde, video yardımlı torakoskopik cerrahi (VATS) ile etkin ve rahat bir tedavi seçeneğidir. Bu yazıda, genel cerrahi tarafından yapılan total tiroidektomi ve paratiroidektomi ameliyatından sonra devam eden klinik ve laboratuvar hiperparatiroidizmli hastanın Tc-99m sintigrafisi ve SPECT ile belirlenen; lateral torakotomi ile başarılı eksize edilen mediastinal paratiroid adenomunu bildirmeyi amaçladık. Hasta L-tyroxine, kalsiyum ve $D$ vitamini replasman tedavileri ile takip aşamasındadır.

Anahtar Sözcükler: Hiperparatiroidizm, adenom, mediastinal, torakotomi.
'Department of Internal Medicine, Health Sciences University, Konya Training and Research Hospital, Konya, Turkey

${ }^{2}$ Department of Thoracic Surgery, Health Sciences University, Konya Training and Research Hospital, Konya, Turkey

${ }^{3}$ Department of Internal Medicine, Division of Endocrinology and Metabolism, Health Sciences University, Konya Training and Research Hospital, Konya, Turkey

${ }^{4}$ Department of General Surgery, Health Sciences University, Konya Training and Research Hospital, Konya, Turkey

\footnotetext{
'Sağlık Bilimleri Üniversitesi Konya Eğitim ve Araşııma Hastanesi Dahiliye Kliniği, Konya

${ }^{2}$ Sağlık Bilimleri Üniversitesi Konya Eğitim ve Araştırma Hastanesi Göğüs Cerrahisi Kliniği, Konya

${ }^{3}$ Sağlık Bilimleri Üniversitesi Konya Eğitim ve Araşıırma Hastanesi Dahiliye Kliniği Endokrinoloji Ve Metabolizma Hastalıkları Servisi, Konya

${ }^{4}$ Sağlık Bilimleri Üniversitesi Konya Eğitim ve Araştırma Hastanesi Genel Cerrahi Kliniği, Konya
}

Submitted (Başvuru tarihi): 06.08.2017 Accepted (Kabul tarihi): 06.09.2017

Correspondence (iletişim): Mustafa Çalık, Department of Thoracic Surgery, Health Sciences University, Konya Training and Research Hospital, Konya, Turkey

e-mail:drmcalik@hotmail.com 
Primary hyperparathyroidism (PHPT) is an endocrine abnormality characterized by an elevated level of serum parathyroid hormone (PTH) and calcium, with an accompanying decreased phosphate level due to the oversecretion of PTH, which may clinically cause fatigue, tiredness, mental alterations (depression, anxiety), renal stones, hypertension, osteoporosis and/or gastric ulcers. It's reported to be 3 times more common in women than men with an overall incidence of $1 / 1000$. It is reported more frequently in the postmenopausal period. In $80 \%$ to $85 \%$ of cases, a solitary parathyroid adenoma is responsible for PHPT; however, hyperplasia (10\%-20\%), multiple solitary parathyroid adenomas $\left(2 \frac{1}{2} \%-3 \%\right)$, and parathyroid cancer (1\%) have also been reported (1).

The indications for surgery in PHPT include $1 \mathrm{mg} / \mathrm{dL}$ or more increase above the upper limit for calcium level, a history of life-threatening hypercalcemia attack, a glomerular filtration rate of lower than $60 \mathrm{~mL} /$ minute, a $T$ score of $\leqslant-2.5$ bone mineral density, or if the patient is younger than 50 years of age (2). An experienced surgeon can treat $95 \%$ of PHPT patients with 1 neck exploration. If HPT continues or recurs after surgery, ectopic parathyroid adenoma should be assumed, and after an exact preoperative localization of the adenoma, a second operation should be considered.

The parathyroid glands are ovoid, encapsulated structures located on anterior neck, posterolateral to the thyroid gland. The superior parathyroid glands develop from the fourth pharyngeal pouch and since they migrate together with the ultimobranchial bodies that generate the lateral thyroid, their localization is generally constant. The inferior parathyroid glands develop from the third pharyngeal pouch and migrate on a longer path together with the thymus; for that reason, an ectopic localization is common. Ectopic parathyroid adenoma accounts for about $5 \%$ to $10 \%$ of all parathyroid adenomas. Although they are most commonly reported in the thymus; they may also be seen in the thyroid gland, hyoid bone, carotid sheath, retro-esophageal region, cervical muscles, hypopharynx, or sublingual or aortopulmonary window. A mediastinal localization is rare; fewer than $5 \%$ of all ectopic parathyroid adenomas have been found in the region $(3,4)$. Presently described is the case of a patient who was treated by thoracic surgeons using a thoracotomic approach in a second surgery subsequent to a diagnosis of mediastinal parathyroid adenoma due to clinical and radiological unresponsiveness after the first PHPT surgery.

\section{CASE}

A 64-year-old woman was admitted to the nephrology outpatient clinic with the complaints of fatigue, tiredness, nausea, excess thirst, diuresis, and a stomachache. She had a history of an operation for a multinodular goiter 10 years prior. Her physical examination was normal. The biochemical analyses revealed a serum calcium (Ca) level of $12 \mathrm{mg} / \mathrm{dL}$ (range: $8.4-10.2 \mathrm{mg} / \mathrm{dL}$ ) and phosphate level of $2.1 \mathrm{mg} / \mathrm{dL}$ (range: $2.7-4.5 \mathrm{mg} / \mathrm{dL}$ ). Her 24 -hour urine Ca level was determined to be $668 \mathrm{mg} /$ day (range: 100-320 mg/day) and the intact parathyroid hormone (level was $113 \mathrm{pg} / \mathrm{mL}$ (range: $7-53 \mathrm{pg} / \mathrm{mL}$ ). She was diagnosed with PHPT. Thyroid ultrasonography revealed multiple nodules with sizes ranging from 16 to $28 \mathrm{~mm}$. She had a bone mineral densitometry lumbar T-score of 3.1, which was consistent with osteoporosis. Parathyroid scintigraphy showed irregular activity in the right inferior thyroid region, which was thought to be residue thyroid tissue or parathyroid adenoma. A CT image of the thorax revealed vertical, tubular, soft tissue $40 \times 15 \mathrm{~mm}$ in size, localized in the right upper paratracheal area, near the esophagus, which was thought to be a lymph node or ectopic thyroid tissue. Surgery was scheduled and a total thyroidectomy and parathyroid exploration was performed. During the operation, all of the parathyroid glands were evaluated and found to be normal. Suspected parathyroid tissue was also removed. Since there was no clinical or laboratory improvement after surgery, the patient was re-evaluated with dual phase Tc-99m MIBI planar parathyroid scintigraphy and SPECT. SPECT revealed activity in the inferior region without thyroid activity. Activity accumulation continued in late images (Figure 1). When the SPECT and previous CT images were re-examined, a mass $25 \times 18 \times 39 \mathrm{~mm}$ in size was observed in the lower retrotracheal region, near the esophagus, which was considered ectopic parathyroid tissue.

A right posterolateral thoracotomy was performed by the thoracic surgeons in a second operation. A capsulated mass in the posterolateral region of the inferior trachea and separated from the surrounding tissues by a clear boundary was observed and palpated. Ten mCi Tc99m MIBI had been given to the patient intravenously before the operation, and the surgical gamma probe (Crystal Photonics $\mathrm{GmbH}$, Berlin, Germany) confirmed high radioactivity in the mass. The mediastinal pleura on the mass was dissected and the mass was separated from the surrounding tissues with the capsule intact using blunt, sharp dissection. It was removed en bloc and the neural and vascular tissues were preserved (Figure 2). Once the mass 
was removed, the high radioactivity level observed previously declined. Gamma probe verification of the removed mass did indicate a high level of radioactivity. A single thoracic tube was inserted. There were no complications reported, and the postoperative period was uneventful. The drain was taken out on the postoperative fifth day and the patient was discharged with L- thyroxine, calcium, and vitamin D replacement therapy to treat the hypothyroidism and HPT resulting from the previous operation.

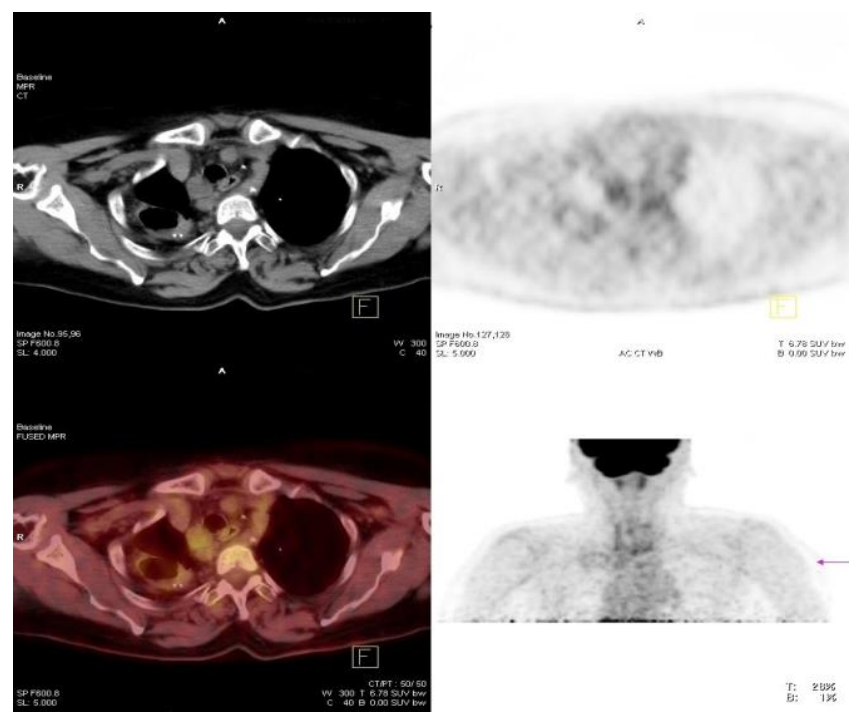

Figure 1: SPECT imaging from coronal plan showing an activity localized on right upper paratracheal region

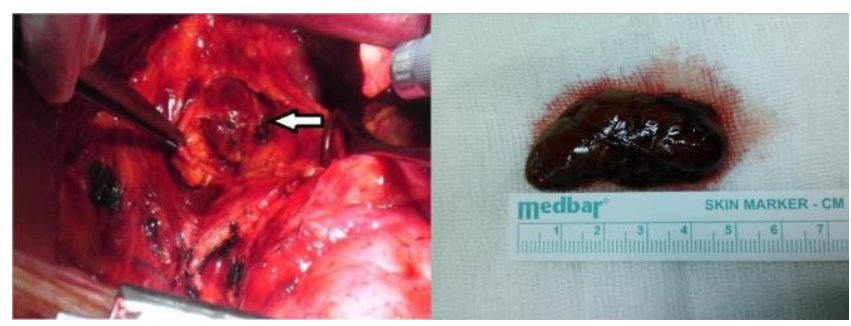

Figure 2: Second surgery and removed parathyroid mass

\section{DISCUSSION}

Tc-99m MIBI scintigraphy, MRI, and thorax CT imaging are used to diagnose ectopic parathyroid adenoma. The sensitivity of ultrasound in the detection of ectopic parathyroid adenoma is very low. Tc-99m MIBI scintigraphy is the most sensitive method and can aid in the diagnosis of almost all cases. Tardin et al. (5) found that parathyroid scintigraphy detected all ectopic parathyroid adenomas. Although rare, to prevent false negative results and to determine the precise localization of the adenoma in the preoperative period, $\mathrm{CT}$ or MRI must also be used in addition to Tc99m-MIBI, and functional and morphological data should be incorporated (6). In conditions where noninvasive methods are unsuccessful, intraoperative parathyroid hormone measurement with selective venous catheterization may aid in diagnosis (7).

The mediastinal localization reported in our case is a very rare localization for a parathyroid adenoma. In a study conducted by Mariette et al. (8), it was reported that $45 \%$ of ectopic parathyroid adenomas were intrathymic, $12.5 \%$ were intrathyroidal, $7.5 \%$ were retroesophageal, $7.5 \%$ were in the carotid sheath, and $5 \%$ were mediastinal. Mc Henry et al. (9) found a prevalence of mediastinal adenomas of $1.3 \%$ in 522 patients with HPT who were surgically treated.

Although Tc-99m MIBI scintigraphy performed to localize the ectopic parathyroid adenomas may reveal activity, nodules smaller than $2 \mathrm{~cm}$ in size may not be found in surgical exploration. Intraoperative use of a gamma probe during a parathyroidectomy to identify the area with the maximum count rate supports the exact localization of ectopic adenomas with high accuracy $(10,11)$. In our case, we measured the radioactivity in the empty parathyroid bed and the thyroid gland, as well as the extracted gland, in order to judge the extensiveness of the resection.

Mediastinal parathyroid adenoma, particularly an anterior mediastinal thymus lesion, is generally treated with a lower anterior cervicotomy. Other treatment options include cervicotomy together with a partial upper sternotomy, partial or total sternotomy, or an anterolateral thoracotomy, in difficult cases.

In this case, an ectopic parathyroid adenoma with an inferior mediastinal localization was treated with a transthoracotomic approach. In visceral mediastinal localizations, video assisted thoracoscopic surgery (VATS) and thoracoscopy are effective and comfortable methods that lessen the thoracotomy and partial/total sternotomy requirements $(12,13)$. Postoperative pain is significantly reduced and healing is improved with VATS.

\section{CONCLUSION}

Mediastinal parathyroid adenoma is a rare cause of PHPT that may be treated successfully with different approaches by experienced thoracic surgeons. After the operation, the metabolic parameters of the patient should be monitored closely, and if required, replacement treatments should be implemented and followed up.

\section{CONFLICTS OF INTEREST}

None declared. 


\section{AUTHOR CONTRIBUTIONS}

Concept - O.Ku., M.Ç., C.D., H.E., O.Ka.; Planning and Design - O.Ku., M.Ç., C.D., H.E., O.Ka.; Supervision O.Ku., M.Ç., C.D., H.E., O.Ka.; Funding - O.Ku., M.Ç., C.D., H.E., O.Ka.; Materials - O.Ku., M.Ç., C.D., H.E., O.Ka.; Data Collection and/or Processing - O.Ku., M.Ç., C.D., H.E., O.Ka.; Analysis and/or Interpretation - O.Ku., M.Ç.; Literature Review - O.Ku., M.Ç.; Writing - O.Ku., M.Ç.; Critical Review - O.Ku., M.Ç.

\section{YAZAR KATKILARI}

Fikir - O.Ku., M.Ç., C.D., H.E., O.Ka.; Tasarım ve Dizayn - O.Ku., M.Ç., C.D., H.E., O.Ka.; Denetleme O.Ku., M.Ç., C.D., H.E., O.Ka.; Kaynaklar - O.Ku., M.Ç., C.D., H.E., O.Ka.; Malzemeler - O.Ku., M.Ç., C.D., H.E., O.Ka.; Veri Toplama ve/veya İşleme - O.Ku., M.Ç., C.D., H.E., O.Ka.; Analiz ve/veya Yorum - O.Ku., M.Ç.; Literatür Taraması - O.Ku., M.Ç.; Yazıyı Yazan O.Ku., M.Ç.; Eleştirel İnceleme - O.Ku., M.Ç.

\section{REFERENCES}

1. Mousa U, Kılıç D, Ekici Y. Ectopic Mediastinal parathyroid adenoma: A case report. Turk Jem 2012; 16:46-8.

2. Udelsman R, Pasieka JL, Sturgeon C, Young JE, Clark $\mathrm{OH}$. Surgery for asymptomatic primary hyperparathyroidism: proceedings of the third international workshop. J Clin Endocrinol Metab 2009; 94:366-72. [CrossRef]

3. Lumachi F, Zucchetta P, Varotto S, Polistina F, Favia G, D'Amico D. Noninvasive localization procedures in ectopic hyperfunctioning parathyroid tumors. Endocr Relat Cancer 1999; 6:123-5. [CrossRef]

4. Caporale DM, Bobbio A, Accordino R, Ampollini L, Internullo $E$, Cattelani $L$, et al. Ectopic mediastinal parathyroid adenoma. Acta Biomed 2003; 74:157-9.

5. Tardin L, Prats E, Andrés A, Razola P, Deus J, Gastaminza $R$, et al. Ectopic parathyroid adenoma: Scintigraphic detection and radioguided surgery. Rev Esp Med Nucl $2011 ; 30: 19-23$. [CrossRef]

6. Phillips $C D$, Shatzkes DR. Imaging of the parathyroid glands. Semin Ultrasound CT MR. 2012; 33:123-9. [CrossRef]

7. Sagan D, Goździuk K. Surgical treatment of mediastinal parathyroid adenoma: rationale for intraoperative parathyroid hormone monitoring. Ann Thorac Surg 2010; 89:1750-5. [CrossRef]

8. Mariette C, Pellissier L, Combemale F, Quievreux JL, Carnaille B, Proye C. Reoperation for persistent or recurrent primary hyperparathyroidism. Langenbecks Arch Surg 1998; 383:174-9. [CrossRef]

9. McHenry C, Walsh M, Jarosz H, Henkin R, Tope J, Lawrence $A M$, et al. Resection of parathyroid tumor in the aorticopulmonary window without prior neck exploration. Surgery 1988; 104:1090-4

10. Rubello D, Casara D, Pagetta C, Piotto A, Pelizzo MR, Shapiro B. Determinant role of Tc-99m MIBI SPECT in the localization of a retrotracheal parathyroid adenoma successfully treated by radioguided surgery. Clin Nucl Med 2002; 27:711-5. [CrossRef]

11. Doğan R, Kara M, Yazicioğlu A, Kaynaroğlu V. The use of gamma probe for the intraoperative localization of an ectopic parathyroid adenoma. Tuberk Toraks 2009; 57:208.

12. Amar L, Guignat L, Tissier F, Richard B, Vignaux $O$, Fulla $Y$, et al. Video-assisted thoracoscopic surgery as a firstline treatment for mediastinal paratyhroid adenomas: strategic value of imaging. Eur J Endrocrinol 2004; 150:141-7.

13. Grozavu C, Pantile D. Primary hyperparathyroidism through an ectopic parathyroid adenoma. Chirurgia (Bucur) 2016; 111:156-60. 